\begin{tabular}{|l|l|l||}
\hline \multicolumn{2}{|c|}{ PublisherInfo } \\
\hline \hline PublisherName & $:$ & BioMed Central \\
\hline \hline PublisherLocation & $:$ & London \\
\hline \hline PublisherImprintName & $:$ & BioMed Central \\
\hline \hline
\end{tabular}

\title{
Deletion bank
}

\begin{tabular}{|l|l|l||}
\hline \multicolumn{2}{|c|}{ ArticleInfo } \\
\hline \hline ArticleID & $:$ & 4540 \\
\hline \hline ArticleDOI & $:$ & $10.1186 /$ gb-spotlight-20020725-02 \\
\hline \hline ArticleCitationID & $:$ & spotlight-20020725-02 \\
\hline \hline ArticleSequenceNumber & $:$ & 206 \\
\hline \hline ArticleCategory & $:$ & Research news \\
\hline ArticleFirstPage & $:$ & 1 \\
\hline \hline ArticleLastPage & $:$ & 2 \\
\hline \hline & & RegistrationDate : 2002-7-25 \\
\hline ArticleHistory & $:$ & OnlineDate \\
\hline ArticleCopyright & $:$ & BioMed Central Ltd2002-7-25 \\
\hline \hline ArticleGrants & $:$ & \\
\hline \hline ArticleContext & $:$ & 130593311 \\
\hline \hline
\end{tabular}




\section{Jonathan B Weitzman}

Email: jonathanweitzman@hotmail.com

Deletion of a particular gene is often the first step to working out its function. In the July 25 Nature, Glaever et al. report the creation of a nearly complete collection of gene-deletion mutants (representing 96\% of all annotated ORFs) of the yeast Saccharomyces cerevisiae (Nature 2002, 418:387-391). They deleted each gene, from start to stop codon, by replacing it with a deletion cassette incorporating the KanMX gene flanked by two distinct 20-nucleotide sequences that serve as unique 'molecular bar codes' for identification. They deleted 5,916 genes in this manner, $18.7 \%$ of which proved to be essential for growth on glucose-rich medium. The unique sequence tags allow strains to be analyzed in parallel. Mixed cultures can be grown and sampled and the abundance of each deletion strain determined by hybridization of genomic DNA to an oligonucleotide microarray of the complementary bar-code sequences. Using this approach, Glaever $e t$ al. monitored and characterized genes required for optimal growth under a range of altered environmental conditions, including high salt, sorbitol, galactose, $\mathrm{pH} 8$, minimal medium and nystatin treatment. This deletion bank provides a powerful tool for future functional genomic studies.

\section{References}

1. Nature, [http://www.nature.com]

2. Saccharomyces Deletion Project, [http://www-deletion.stanford.edu] 